\title{
The Plague Year Revisited
}

Another Plague Year would reconcile all these Differences, a close conserving with Death or with Diseases that threaten Death, would scum of all the Gall from our Tempers, remove the Animosities among us, and bring us to see with differing Eyes than those which we look'd on Things with before.

Daniel Defoe $^{1}$

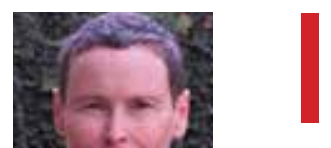

n April 2020, I pledged to focus my editorials on the pandemic. In subsequent editorials I renewed that intention. And it is a promise I have kept during the long plague year for all my editorials. When I announced my plan to write solely on COVID-19, my astute editor asked me, "How are you going to know when to stop?" I reminded myself of his question as I sat down to write each month and never arrived at a satisfactory answer. Nor do I have an answer now for why I am asking readers to release me from my vowexcept for the somewhat trivial reason that a year seems enough. Is there more to say about the pandemic? Yes, there is so much more that needs to be discovered and unraveled, contemplated and analyzed; no doubt oceans of print and electronic pages will wash over us in the coming decade from thousands of scientists and journalists commenting on the topic of this public health crisis. ${ }^{2}$

Nevertheless, I have run the gauntlet of salient subjects within my wheelhouse: The plague year of editorials opened with a primer on public health ethics; the May column studied the duty to care for health care professionals in the midst of the first surge of virus; June examined the controversy around remdesivir and hydroxcholoroquine as medicine frantically sought some way to treat the sick; in July, I took a lighter look at the "Dog Days" of COVID-19 staring my Labrador Retriever mix, Reed, snoozing on his couch on the patio; August celebrated the amazing outreach of the US Department of Defense, US Public Health Service, and US Department of Veterans Affairs (VA) in service to the community; September discussed the adverse effects of the prolonged pandemic on the human psyche and some positive ways of handling the stress; October lamented the exponential rise in substance misuse as human beings struggled to manage the emotional toll of the pandemic; in December, COVID-19 was the sole subject of my annual Best and Worst ethics column; the new year saw the emergency use authorizations of the first and second vaccines and the editorial laid out the critical challenges for vaccination; in February my esteemed colleague Anita Tarzian joined me in an article explaining the ethical approach to vaccine allocation developed by the VA. ${ }^{3-12}$

A reader might aptly ask whether I am laying down the COVID-19 gauntlet because I believe the pandemic is over and done with us. The news is full of pundits opining when things will return to normal (if that ever existed or will again) and soothsayers divining the signs of the plague's end. ${ }^{13}$ What I think is that we are more than done with the pandemic and unfortunately that may be the central cause of its perpetuation; which brings me to Daniel Defoe's A Journal of the Plague Year. ${ }^{1}$

Defoe is better known to most of us if at all from modern films of his best-seller Robinson Crusoe. Yet A Journal of the Plague Year and other books about epidemics have become popular reading as we seek clues to the mystery of how to affirm life amid a death-dealing infectious disease. ${ }^{14}$ There is even an emerging lockdown literature genre. (Before anyone asks, I am in no way so pretentious as to suggest my columns should be included in that scholarly body of work)

Defoe's book chronicles the last episode of the bubonic plague that afflicted London in 1665 and claimed 100,000 lives. Defoe was only 5 years old when the epidemic devastated one of the greatest cities in Europe. In 1772 he published what one recent reviewer called "a fascinating record of trying to cope with the capital's last plague." ${ }^{15}$ Defoe presciently documented the central reason I think the pandemic 
may not end anytime soon despite the increasing success of vaccination, at least in the United States. "But the Case was this...that the infection was propagated insensibly, and by such Persons, as were not visibly infected, who neither knew who they infected, or who they were infected by."1

Ignorance and apathy are not confined to the streets of 17th century England: We see state after state lift restrictions prematurely, guaranteeing the scientists prediction that the wave now hitting Europe could again breach our shores. Defoe wrote long before germ theory and the ascendancy of public health, yet he knew that the inability or unwillingness to stick close to home kept the plague circulating. "And here I must observe again, that this Necessity of going out of our Houses to buy Provisions, was in a Great Measure the Ruin of the whole City, for the people catch'd the Distemper, on those Occasions, one of another..." While provisions may equate to food for many, for others necessities include going to bars, dining inside restaurants, and working out at gyms - all are natural laboratories for the spread and mutation of COVID-19 into variants against which physicians warn that the vaccine may not offer protection.

Defoe's insights were at least in part due to his distance from the horror of the plague, which enabled him to study it with both empathy and objectivity, critical thinking, and creative observation. Similarly, it is time to take a brief breathing space from the pandemic as the central preoccupation of our existence: not just for me but for all of us to the extent possible given that unlike Defoe's epoch it is still very much our reality. Even a few moments imagining a world without COVID-19 or more accurately one where it is under some reasonable control can help us reconceive how we want to live in it.

Can we use that luminal period to reenvision society along the lines Defoe idealistically drew even while we contribute to the collective search for the Holy Grail of herd immunity? During this second plague year, in coming editorials and in my own small circle of concern I will try to take a different less frustrated, embittered view of our lives scarred as they may be. It is only such a reorientation of perspectives in the shadow of so much death and suffering that can give us the energy and empathy to wear masks, go only where we must, follow public health measures and direction, and persuade the hesitant to be vaccinated so this truly is the last plague year at least for a long, quiet while.

\section{Disclaimer}

The opinions expressed herein are those of the author and do not necessarily reflect those of Federal Practitioner, Frontline Medical Communications Inc., the US Government, or any of its agencies.

\section{References}

1. Defoe D. A Journal of the Plague Year. Revised edition. Oxford World Classics; 2010

2. Balch BT. One year into COVID, scientists are still learning about how the virus spreads, why disease symptoms and severity vary, and more. Published March 11, 2021. Accessed March 22, 2021. https://www.aamc.org/news -insights/one-year-covid-scientists-are-still-learning-about -how-virus-spreads-why-disease-symptoms-and

3. Geppert CMA. The return of the plague: a primer on pandemic ethics. Fed Pract. 2020;37(4):158-159.

4. Geppert CMA. The duty to care and its exceptions in a pandemic. Fed Pract. 2020;37(5):210-211.

5. Geppert CMA. A tale of 2 medications: a desperate race for hope. Fed Pract. 2020;37(6):256-257.

6. Geppert CMA. The dog days of COVID-19. Fed Pract. 2020;37(7):300-301.

7. Geppert CMA. All hands on deck: the federal health care response to the COVID-19 national emergency. Fed Pract. 2020;37(8):346-347. doi:10.12788/fp.0036

8. Geppert CMA. The brain in COVID-19: no one is okay. Fed Pract. 2020;37(9):396-397. doi:10.12788/fp.0046

9. Geppert CMA. The other pandemic: addiction. Fed Pract. 2020;37(10):440-441. doi:10.12788/fp.0059

10. Geppert CMA. Recalled to life: the best and worst of 2020 is the year 2020. Fed Pract. 2020;37(12):550-551. doi: $10.12788 /$ fp. 0077

11. Geppert CMA. Trust in a vial. Fed Pract. 2021;38(1):4-5. doi:10.12788/fp.0084

12. Tarzian AJ, Geppert CMA. The Veterans Health Administration approach to COVID-19 vaccine allocation-balancing utility and equity. Fed Pract. 2021;38(2):52-54. doi:10.12788/fp.0093

13. Madrigal AG. A simple rule of thumb for knowing when the pandemic is over. Published February 23, 2021. Accessed March 22, 2021. https://www.theatlantic.com/health /archive/2021/02/how-know-when-pandemic-over/618122

14. Ford-Smith A. A Journal of the Plague Year book review. Med History. 2012;56(1):98-99. doi:10.1017/S0025727300000338

15. Jordison S. A Journal of the Plague Year by Daniel Defoe is our reading group book for May. The Guardian. Published April 28, 2020. Accessed March 22, 2021. https://www .theguardian.com/books/booksblog/2020/apr/28/a-journal -of-the-plague-year-by-daniel-defoe-is-our-reading-group -book-for-may 